\title{
A hipótese Podemos: a emergência de uma nova alternativa política na Espanha pós-crise Javier Amadeo ${ }^{2}$
}

\section{Resumo}

O surgimento da organização política Podemos teve um enorme impacto político na Espanha e na Europa. Em pouco mais de quatro anos de existência, Podemos se converteu em uma das principais forças políticas do país. Com a discussão sobre as razões desse surpreendente nascimento, começou também um debate sobre sua identidade política: diferentes autores têm caracterizado essa organização como uma nova versão da social-democracia, uma nova esquerda radical ou uma versão do populismo. O objetivo do presente artigo é discutir a questão da identidade política de Podemos, recuperando esse debate e analisando os elementos conceituais presentes em seus documentos e na análise de seus dirigentes. Como parte deste objetivo, busca-se discutir a identidade política de Podemos no marco do debate sobre o fenômeno populista.

Palavras-chave: Populismo. Podemos. Espanha. Democracia.

I O presente texto é resultado de um período de trabalho como pesquisador visitante na Universidad Complutense de Madrid (UCM) sob supervisão do Prof. Juan Carlos Monedero; por isso, gostaria de registrar aqui meu agradecimento. Várias ideias e argumentos desenvolvidos no artigo são produto de conversas com o Prof. Monedero e com dirigentes da organização Podemos. Em particular, gostaria de agradecer Fran Casamayor, María Espinosa e Ramón Espinar. De qualquer forma, as opiniões aqui colocadas são da minha exclusiva responsabilidade.

2 Licenciado em Ciência Política pela Universidad de Buenos Aires (UBA). Possui doutorado em Ciência Política pela Universidade de São Paulo (USP) e pós-doutorado em História pela mesma instituição. Atualmente é professor do Departamento de Ciências Sociais e do Programa de Pós-graduação em Ciências Sociais da Escola de Filosofia, Letras e Ciências Humanas (EFLCH) da Universidade Federal de São Paulo (Unifesp). E-mail: javier. amadeo@unifesp.br Commons. Com essa licença você pode compartilhar, adaptar, para qualquer fim, desde que atribua a autoria da obra, forneça um link para a licença, e indicar se foram feitas alterações. 


\section{Introdução}

No dia 14 de janeiro de 2014 foi lançado o manifesto intitulado "Mover ficha: convertir la indignación en cambio político" , documento fundador da organização política Podemos. O documento afirma a necessidade de uma candidatura para as eleiçóes do Parlamento Europeu que represente a “indignação popular que tem surpreendido o mundo". Poucos dias depois, em 17 de janeiro, colocou-se o desafio de conseguir 50 mil assinaturas para o lançamento de uma candidatura cidadá, encabeçada por Pablo Iglesias Turrión, cifra que foi alcançada nas primeiras 36 horas (JEREZ; MACEIRAS; MAESTU, 2015, p. 1578). Quatro meses depois do lançamento do documento, nas eleiçóes de 25 de maio, Podemos se transformaria na quarta força política da Espanha, com 1.253.000 votos, 7,98\% do total, obtendo cinco cadeiras no Parlamento Europeu e sendo a surpresa eleitoral da jornada (GÁLVEZ; KADNER, 2014)4.

Nas eleições gerais do ano seguinte (2015) para o Parlamento espanhol, Podemos continuou sendo a surpresa eleitoral. Com pouco mais de um ano de existência, a força política comandada por Pablo Iglesias conseguiu mais de cinco milhóes de votos em todo o país, equivalente a $20 \%$ do total, elegendo 69 deputados de um total de 350 (EL PAÍS, 2015) Podemos também se transformou, sozinha ou mediante coligaçóes, como En Comù (Catalunha) e En Marea (Galícia), na primeira força política no País Basco e na segunda força política em comunidades como Madri, Catalunha, Galícia e na Comunidade Valenciana, capitalizando um sentimento de indignação com a classe política do país e expressando uma esperança de mudança social. Nas eleiçóes gerais de dezembro de 2015 e de junho de 2016, Podemos se consolidou como a terceira força eleitoral em nível nacional, ficando muito próximo do tradicional Partido Socialista Obrero Español (PSOE) ${ }^{6}$.

3 Cf. Mover ficha: convertir la indignación en cambio político, disponível em: http:/tratarde.org/wp-content/ uploads/20I 4/0I/Manifiesto-Mover-Ficha-enero-de-20I4.pdf. As traduções deste trecho do texto e de todos os outros que aparecem originalmente em espanhol são de nossa autoria.

4 GÁlVEZ, J. J.; KADNER, M. Cf. reportagem "Podemos se convierte en la sorpresa y logra cinco escaños en Estrasburgo", publicada em El País, em 25 maio de 2015. Disponível em http://politica.elpais.com/politica/2014/05/25/ actualidad/1401009854_060215.html.

5 Cf. Total España. Disponivel em: http://resultados.elpais.com/elecciones/2015/generales/congreso/.

6 Sobre os resultados eleitorais e os impactos no sistema partidário, ver: Simón, 2017. 
O surgimento da organização Podemos teve um enorme impacto político não somente na Espanha, mas na Europa como um todo. O nascimento dessa força parece fazer parte de um processo mais amplo de surgimento de forças políticas que questionam a legitimidade da ordem política no continente. Organizações como o Movimento 5 estrelas na Itália, a frente França insubmissa ou o triunfo de Corbyn no interior do Partilho Trabalhista na Inglaterra parecem ser expressão de um sentimento de mudança ${ }^{7}$.

Do ponto de vista teórico, iniciou-se uma discussão para entender as propriedades teóricas e intelectuais de Podemos. Diferentes autores têm caracterizado essa organização como uma nova versão da social-democracia, como uma nova esquerda radical ou como uma versão europeia do populismo.

A questão teórica e analítica que se coloca é como entender esse surpreendente fenômeno político que tem provocado uma transformação na estrutura partidária e aberto um conjunto de discussóes na sociedade espanhola sobre o processo de transição democrático, a questão da mudança nas sociedades contemporâneas e a questão do papel da comunicação na política, para citar só algumas delas.

O objetivo deste artigo é analisar o momento de emergência da organização política Podemos como uma estrutura política original, radical e progressista, que aparece como parte de um processo de ruptura no sistema político anterior, buscando entender as influências intelectuais, políticas, ideológicas e organizativas que confluíram para essa construção. Um objetivo mais específico é discutir e analisar os elementos centrais da formulação original da hipótese Podemos, os elementos teóricos e conceituais presentes nos documentos políticos e organizativos e nas análises realizadas por seus principais dirigentes e intelectuais. Também como parte deste objetivo, busca-se analisar a hipótese Podemos como componente do debate sobre o fenômeno populista e sobre a possível identidade populista dessa organização política.

$\mathrm{O}$ artigo centra sua análise nos momentos políticos fundacionais que vão desde o surgimento de Podemos em janeiro de 2014 até a II Assembleia Cidadã realizada em fevereiro de 2017, na qual foram definidos um

7 Para uma análise deste processo, ver: Watkins, 2016. 
conjunto de documentos centrais para os propósitos desta análise. Este período será central na orientação inicial da organização e, especialmente, na formulação da hipótese Podemos como veremos a seguir.

\section{Contexto político e social da emergência de Podemos}

No intuito de entender a emergência de Podemos e o efeito que provocou na vida política, é fundamental analisar o contexto social e político no qual essa formação política surgiu. Alguns fatores fundamentais nos permitem ajudar a compreender as situações que precederam a sua irrupção ${ }^{8}$.

Um primeiro elemento importante, ainda que possa ser entendido como antecedente mais distante, relaciona-se ao processo de participação política dos jovens no movimento estudantil das universidades e em um conjunto de coletivos que surgiram durante o processo de mobilização antiglobalização e contra o Plano Bolonha e que terão papel fundamental no processo de articulação político e social que culminará nas mobilizaçóes do 15 de maio de 2011.

Alguns desses grupos - por exemplo, o coletivo Contrapoder ${ }^{9}$ - tinham como inspiração os movimentos antiglobalização que tiveram participação ativa em diversas açóes na Europa durante os anos de 2000 e $2001^{10}$. Os grupos e movimentos antiglobalização, como sustenta Giménez (2014a), deram expressão às novas geraçóes de jovens que não encontravam espaço para colocar suas demandas ou formas de organização nos instrumentos tradicionais da esquerda. Do ponto de vista tanto do discurso quanto das práticas políticas, a ideia de desobediência passou a ter papel central na ação coletiva desses grupos (GIMÉNEZ, 2014a, p. 24-25).

8 Ver: Pastor, 2015; Oñate, 2013; Domínguez e Giménez, 2014; Torreblanca, 2015.

9 A associação universitária Contrapoder surgiu na Faculdade de Ciências Políticas e Sociologia da Universidad Complutense de Madrid (UCM) no ano de 2006. Vários membros desse coletivo, como Pablo Iglesias, Iñigo Errejón, Jorge Moruno, Tania González e Pablo Gabandé, participaram da proposta de comunicação alternativa conhecida como La Tuerka e também da fundação de Podemos (GIMÉNEZ, 20I4a, p. 20). Ver, também o vídeo "Ação de Contrapoder na Universidade Complutense de Madrid", disponível em: https://www.youtube.com/ watch?v=NoIXU5a4alQ.

10 No caso do coletivo Contrapoder, uma das principais referências era o grupo italiano Tute Bianche, movimento autônomo que teve papel destacado nas mobilizações antiglobalização, especialmente em Gênova em 200I, e que inovou com relação às práticas de ação coletiva durante esse ciclo de mobilizações (GIMÉNEZ, 20I4a, p. 20). 
A experiência dessas mobilizações teve enorme importância para uma geração de jovens que participava desses novos movimentos". Para Giménez, duas questóes apareciam como elementos centrais desse processo: em primeiro lugar, a importância da comunicação política: a experiência do Exército Zapatista foi um exemplo do lugar que a comunicação devia ocupar em qualquer processo político; em segundo, a aposta em manter a luta no âmbito do social, fora dos partidos de esquerda tradicionais, e buscando o surgimento de novas identidades e novas formas de organização que tivessem maior potencial de mobilização política (GIMÉNEZ, 2014a, p. 24-25).

Como afirma Giménez, durante os primeiros anos da década de 2000 também começou um importante processo de mobilização estudantil contra a instauração do Espaço Europeu de Educação Superior, conhecido como Plano Bolonha. Esse movimento rapidamente deu lugar a um conjunto de conflitos contra os cortes orçamentários na educação propostos pelo Partido Popular durante o período de 2007 a 2010. Esse processo de mobilização, depois de um longo período de desarticulação política, deu lugar ao surgimento de novas propostas de participaçáo e de organizaçáo. Nesse movimento contra a reforma de Bolonha "[...] formou-se uma geração de ativistas que depois teriam destacada relevância - ainda que não sempre de maneira visível - na configuração do movimento $15 \mathrm{M}$ e, posteriormente, também de Podemos" (GIMÉNEZ, 2014a, p. 24).

Algumas das associações e coletivos de estudantes que tinham participado do processo de luta contra a implantação do Plano Bolonha, entre eles a agrupação Contrapoder, começaram a discutir a necessidade de criar coletivos que conseguissem transcender os limites colocados pela universidade, a fim de contribuir com o processo de mobilização e de luta por reivindicaçóes mais amplas, especialmente as relacionadas com as condiçóes de precariedade do emprego e de diminuiçáo de direitos sociais para os jovens. Como parte desse processo surgiu o coletivo Juventud sin futu$r o^{12}$, que rapidamente se transformou em referência no ativismo juvenil. Para Giménez (2014a, p. 25), a influência desse movimento no período

I I Pablo Iglesias, principal dirigente de Podemos, foi um dos porta-vozes do Movimento de Resistencia Global de Madrid (GIMÉNEZ, 20I4a, p. 20). A tese doutoral de Pablo Iglesias é uma reflexão sobre essa experiência. Ver: Iglesias Turrión, 2008.

12 Sobre esse coletivo, ver: Errejón, 201 Ia. 
posterior relaciona-se não só com sua capacidade organizativa ou escolha adequada das principais críticas referentes ao desemprego e à precariedade, mas também com a ascensão do processo de mobilização política da sociedade espanhola que culminou com o movimento do 15-M.

O segundo elemento contextual vincula-se à crise econômica que teve início nos Estados Unidos em 2008, com o estouro da bolha imobiliária, e posteriormente se espalhou por várias economias do mundo, e seus desdobramentos de crise social e política. Os efeitos na economia espanhola foram profundos: o PIB caiu 3,8\% em 2009, o desemprego mais que dobrou, chegando a uma taxa de $20 \%$, e a dívida pública ultrapassou a marca de $100 \%$ em relação ao PIB. A face mais dramática da crise foi o aumento da pobreza e da desigualdade social, revelado, por exemplo, nos mais de cem mil despejos por ano que começaram a ser executados por causa da impossibilidade de as pessoas pagarem suas dívidas com os bancos (SOLA; RENDUELES, 2017, p. 3) '. $^{13}$

Uma das consequências da crise econômica foi, como afirmam Sola e Rendueles, a erosão das bases materiais da legitimidade do sistema político espanhol que tinham permitido a existência de um forte bipartidarismo desde o retorno da democracia no país (SOLA; RENDUELES, 2017, p. 3). Com o início da crise econômica, o governo de Rodríguez Zapatero, do Partido Socialista Obrero Español (PSOE), iniciou uma política de redução de gastos sociais que teve como resultado o aprofundamento da recessão econômica e da crise social. A mudança de orientação do governo de Rodríguez Zapatero em 2008 para uma política de austeridade, afirma Pastor, evidenciou o fracasso das expectativas sociais colocadas no modelo de "capitalismo popular", construído desde o período da transição, com a perda de um conjunto de conquistas sociais que haviam sido preservadas até esse momento (PASTOR, 2015, p. 56).

Como afirma Carolina Bescansa (2014, p. 120), quando a crise de 2008 irrompeu, houve importantes sinais de descontentamento social; no entanto, em termos de seus efeitos políticos e ideológicos, estes só foram sentidos plenamente dois anos depois. Foi no ano de 2010 que chegaram novos desdobramentos da crise e os cidadãos passaram a perceber os

13 Sobre as consequências sociais da crise, ver: Mari-Klose e Martínez Pérez, 2016. 
efeitos profundos de uma crise estrutural, quando, então, começaram a ser colocados em questão os consensos que foram construídos durante o processo de transição.

Por um lado, prossegue a autora, foi colocado em questáo um primeiro consenso que sustentava que a democracia era sinônimo de bem-estar social. Esse consenso foi quebrado no momento em que começaram a ser sentidos os efeitos dos cortes no sistema de bem-estar, em particular quando o governo decidiu aceitar as medidas de austeridade exigidas pela União Europeia. Ao mesmo tempo foi questionada a ideia do desenvolvimento entendido como progresso linear, que implicava que, com o passar do tempo, as condiçôes econômicas e sociais necessariamente melhorariam. Foi no ano de 2010 que esse consenso começou a ser impugnado; pela primeira vez, desde o final da guerra civil, a situação econômica e social das famílias piorou de forma dramática (BESCANSA, 2014, p. 120-121).

Um segundo consenso questionado com a crise foi a ideia de que a União Europeia era garantia na construção do bem-estar. Essa ideia, construída nas últimas décadas do século anterior, entrou em crise quando o Banco Central Europeu começou a exigir a aplicação de medidas de austeridade como forma de garantir o pagamento da dívida pública; a União Europeia passou, entáo, a ser associada com a austeridade (BESCANSA, 2014, p. 121).

Outro elemento central desse processo foi que, a partir da crise de 2010, se estabeleceu uma reflexão crítica do ponto de vista da cidadania sobre o conceito de democracia, isto é, um questionamento da representatividade dos setores políticos, do domínio da corrupção sobre o campo da política e do conceito de cidadania que vigorou desde os anos 1980 até princípios do século XXI. Essa reflexão teve seu ponto de inflexão, ainda que de forma não completamente estruturada, com a irrupçáo do 15M. Para Bescansa (2014, p. 121): "O 15M foi o primeiro movimento para uma generalização dessa crítica sobre os conceitos de cidadania e democracia".

O terceiro elemento central desse contexto foram os acontecimentos de 15 de maio de 2011 (15M), ou movimento dos indignados. O movimento $15 \mathrm{M}$ ou dos indignados foi convocado por diversos coletivos articulados fundamentalmente via redes sociais que chamou a uma grande manifestação no dia 15 de maio de 2011 na Puerta del Sol com o objetivo 
de criticar o domínio da política pelos bancos e pelo sistema financeiro e exigir uma democracia mais participativa ${ }^{14}$.

Os protestos tinham como objetivo expressar a indignação com relação à crise econômica e ao funcionamento do sistema político e de representação; slogans como "Não somos marionetes nas mãos de políticos e banqueiros" ou "Democracia real já!" 15 eram sintomáticos dos objetivos fundamentais do movimento ${ }^{16}$. Resultado da mudança de conjuntura descrita anteriormente, criou-se um sentimento de crescente descontentamento que permitiu a diversos grupos sociais, com expressão social bastante limitada até esse momento, a construção de uma estratégia de mobilização nas redes sociais que teve como resultado a manifestação do $15 \mathrm{M}$ e a ocupação de Puerta del Sol, lugar simbólico de manifestaçôes políticas no centro de Madri. Essas mobilizaçóes tiveram como consequência um processo de repolitizacão de setores importantes da população e o ingresso de uma nova geração de lideranças políticas e sociais que serão de fundamental importância na formação de Podemos (PASTOR, 2015, p. 55-56).

Para Ońate (2013), as manifestaçóes do 15M conseguiram "acordar” a sociedade espanhola, que parecia até esse momento estar submersa na apatia ou indiferença política, impugnando, de forma incisiva, a insuficiência da democracia realmente existente no país e exigindo uma democracia real. Desde seu início, uma das características distintivas do movimento foi a amplitude ideológica e programática, permitindo a colaboração entre diferentes organizaçóes e redes, admitindo diversas adesóes coletivas e individuais e possibilitando uma articulaçáo perante demandas diversas. Além do questionamento da ordem existente, o movimento do $15 \mathrm{M}$ conseguiu colocar na agenda pública um importante número de reivindicaçôes relativas a um conjunto de assuntos políticos, sociais e econômicos ${ }^{17}$.

14 Sobre esse movimento, ver também Taibo et al., 201 I; e Romanos, 2011.

15 Manifesto do movimento disponível em: http://www.democraciarealya.es/manifiesto-comun/.

I6 Mais informações, consultar: http://politica.elpais.com/politica/201 I/05/16/actualidad/I305580548_268992. html. 2017.

17 Algumas das reivindicações surgidas nesse processo foram: I) Reforma eleitoral buscando uma democracia mais proporcional e desenvolvimento de mecanismos de participação da cidadania; 2) luta contra a corrupção política por meio de normas orientadas a uma total transparência política; 3) separação efetiva dos poderes públicos; 4) criação de mecanismos de controle cidadão para a existência efetiva da responsabilidade política [Assembleia Geral, Puerta del Sol, 25 de maio de 201 I] (TAIBO et. al, 201 I, p. 92). 
Os debates iniciais que aconteceram durante o processo de mobilizaçáo tiverem desdobramentos no surgimento de comissóes e assembleias setoriais que foram organizadas em distintos bairros do país e que se consolidaram em um conjunto de documentos e propostas de índole diversa, mas orientados de forma geral para mudanças no sistema político, econômico e social (ONATE, 2013, p. 32-33) ${ }^{18}$.

Para Sola e Rendueles, no discurso do $15 \mathrm{M}$ era possível identificar dois eixos claros, que posteriormente seriam retomados por Podemos. Em primeiro lugar, um eixo de crítica ao sistema político, condenando a corrupção e exigindo dos políticos maior transparência e representatividade. Em seguida, uma crítica ao sistema econômico, especialmente aos cortes no orçamento, ao ajuste fiscal e aos lucros das grandes empresas e dos bancos (SOLA; RENDUELES, 2017, p. 4).

O processo de mobilização do $15 \mathrm{M}$ teve como resultado, afirma Pastor, a abertura de um novo ciclo de lutas políticas. Esse ciclo contou com alguns antecedentes importantes, como a Plataforma de Afectados por la Hipoteca (PAH), organização que buscava impedir o despejo das famílias que não conseguiam pagar suas dívidas hipotecárias com os bancos - muitas dessas famílias eram os principais atingidos pela crise econômica, desempregados e vítimas do processo de empobrecimento. Um dos desdobramentos desse novo ciclo de lutas foi o importante fenômeno de mobilizaçóes conhecido como Las Mareas (as Marés), em defesa da saúde pública (La Marea Blanca) ou da educação (La Marea Verde), e outras iniciativas inspiradas no movimento do 15M (PASTOR, 2015, p. 55-56).

Para Oñate, o processo de mobilização do $15 \mathrm{M}$ teve elementos extremamente originais e gerou uma dinâmica bastante peculiar com relação a movimentos anteriores. Alguns desses elementos foram: as organizaçóes e os meios utilizados para convocar as manifestaçóes; as características dos seus participantes, pessoas com pouca experiência anterior em mobilizaçóes e sem vínculos organizativos; e também do ponto de vista do seu impacto na mídia e do amplo e heterogêneo apoio conseguido nas demandas e formas de

18 Várias das propostas elaboradas durante o processo de mobilização serão retomadas posteriormente por Podemos. 
protesto $^{19}$. Sem dúvida, um elemento diferencial com relação a mobilizaçôes anteriores foi o efeito da crítica à situaçáo econômica, elemento catalisador no questionamento das formas tradicionais de mobilização e que deu lugar a novas formas de expressão de protesto, novas formas de manifestaçáo política no marco de um novo paradigma comunicativo. O 15M, prossegue o autor, significou o surgimento de uma consciência crítica plena de lucidez e frescor que abriu a possibilidade de novos caminhos de auto-organização e estabeleceu uma clara dicotomia entre o país oficial das instituiçóes e o país real do novo ativismo (ONATE, 2013, p. 35) ${ }^{20}$.

O movimento do $15 \mathrm{M}$ teve também um efeito catalisador sobre os futuros membros de Podemos. A análise que começa a ser desenvolvida sugere que o $15 \mathrm{M}$ expressava a expansão da indignação social e de protesto, com a possibilidade de ter uma caráter destituinte similar a outros processos que haviam ocorrido em vários países América Latina ${ }^{21}$. A partir do ponto de inflexão era necessário um diagnóstico mais bem articulado sobre os acontecimentos, e surgia também uma janela de oportunidades ${ }^{22}$.

\section{I A hipótese Podemos}

Por trás do surgimento de Podemos como força política alternativa e radical no cenário político espanhol existia, da parte da futura direção de Podemos, uma análise da situação da Espanha e das condiçôes de possibilidade para o surgimento de uma alternativa política capaz de representar os setores sociais descontentes com a situação do país.

A questão central que se colocava, como afirma Iglesias Turrión, era se existiam possibilidades para um populismo de esquerda na Espanha. Ou, colocado de outra forma, se nas condiçóes de uma crise do regime político espanhol, seria possível construir discursivamente uma identidade popular que fora politizável eleitoralmente. Na avaliação de Iglesias Turrión

19 Segundo dados do Barômetro do Instituto de Investigaciones Sociales do mês de julho de 201 I, $70 \%$ dos entrevistados tinham uma imagem positiva do processo de mobilizações do movimento 15M, ou dos Indignados, que ocupavam Puerta del Sol e outros espaços públicos. Informações disponíveis em: http://datos.cis.es/pdf/ Es2905mar_A.pdf.

20 O autor retoma aqui um artigo de Fernando Vallespín publicado no jornal El País, em I de março de 2013.

21 Sobre esta leitura ver, entre outros: Errejón, 2014b, p. 94-97.

22 Sobre a relação entre o I5M e Podemos, ver: Marzolf e Ganuza, 2016. 
(2015a, p. 21), o desafio era agregar as novas demandas derivadas da crise econômica e social em torno de uma "liderança midiática com capacidade de dicotomizar o espaço político".

Como afirma o autor, discutindo o surgimento de Podemos, colocava-se na situação de crise política a possibilidade de constituição de um populismo de esquerda:

$\mathrm{Na}$ Espanha existia uma crise orgânica e de regime que tinha gerado as condições para a articulação de um discurso dicotomizador capaz de construir com os materiais ideológicos novos do $15 \mathrm{M}$ um sujeito popular perante as elites. A hipótese não era uma reflexão nova entre boa parte dos fomentadores de Podemos; tinha começado a ser construída a partir das nossas reflexões sobre o movimento $15 \mathrm{M}$. Aquele processo de reflexão contava com um conjunto de experiências políticas de referência e um dispositivo político para a comunicação muito preciso: as experiências latino-americanas da chamada década conquistada, por um lado, e nosso programa de televisão La Tuerka por outro. (IGLESIAS TURRIÓN, 20I5a, p. 20-2I).

Poderíamos sintetizar um conjunto de elementos centrais para entender a hipótese Podemos ${ }^{23}$.

Em primeiro lugar, a contribuição das experiências políticas latino-americanas (em particular os casos de Bolívia, Equador e Venezuela). Essas experiências, na análise de Iglesias Turrión e também de boa parte dos dirigentes políticos de Podemos, trouxeram novos instrumentos teóricos para entender a situação política espanhola e para pensar a construção de ferramentas políticas originais para sua superação. A crise era assim entendida como a abertura da estrutura de oportunidades políticas.

Iñigo Errejón (2014b, p. 103) afirmava sobre a hipótese Podemos:

Estávamos construindo a hipótese é já tínhamos vários persuadidos. Ao mesmo tempo, em paralelo, La Tuerka e Fort Apache iam incrementando seu impacto político e discursivo e Pablo [Iglesias] começou a ir aos grandes meios televisivos. Isso construiu, ainda que não de forma intencional no começo, algo que era necessário para nossa hipótese e que não tínhamos: uma liderança midiática [...] essa liderança era a constatação de que o discurso funcionava, um discurso que propunha assaltar os significantes flutuantes ou parcialmente vazios que podiam receber interpretações distintas e que até esse momento só estavam em possessão dos poderosos, como democracia, justiça, país, pátria ou decência.

23 Cf. Iglesias Turrión, 2015b, p. 91-1 17. Sobre a hipótese Podemos, ver também: Iglesias Turrión, 2016, p. 15-21; Errejón, 2014a, p. 22-31, e 2014b, p. 102-105. 
As experiências dos países latino-americanos tiveram grande importância para a reflexão sobre o sujeito político do processo de transformação social e foram ponto de partida para a análise da hipótese Podemos realizada pela direção de Podemos, e em especial formulada teoricamente por Iñigo Errejón.

$\mathrm{Na}$ situação política e social da Espanha seria possível, na visão de Errejón, pensar na construção de um populismo de esquerda como sujeito político do processo de mudança. Nessa leitura, e tomando como referência os trabalhos de autores como Ernesto Laclau e Chantal Mouffe (1987), a construção de sujeitos é resultado eminentemente da produção de sentido, o que engendra distintos tipos de identidades. No caso da constituição dos sujeitos políticos, a contingência é fundamental para compreender o cenário político como um conjunto de relaçóes de poder que sempre têm de ser negociadas. Para Errejón, seguindo a leitura de Laclau e Mouffe, são os significantes das palavras, e não os significados, os depositários de certa legitimidade, que têm papel central no processo de articulação política. Esses significantes possibilitam a construção de novas identidades; os significantes vazios são campos de batalha ideológicos (ERREJÓN, 2014a, p. 31-34) ${ }^{24}$.

Para Errejón, os significados são relativamente estáveis e fixos quando estão integrados no interior de um discurso hegemônico que garante a continuidade da dominaçáo social; no entanto, em momentos de crise de hegemonia, como no caso da Espanha depois de 2011, abrem-se fendas e os significantes centrais do discurso deixam de ter a estabilidade anterior, desencadeando a luta pelo sentido desses significantes. Nestes momentos: "[o]s de baixo poderiam produzir uma cadeia de equivalências e depois mediante o uso de significantes vazios - conformar uma visão alternativa do que acontece que seja capaz de oferecer novas formas de orientar a ação política"; essa tem sido, prossegue Errejón, "a estratégia política de Podemos desde sua fundação” (ERREJÓN, 2014b, p. 35).

Um exemplo dessa tentativa de fixação dos termos do enfrentamento é a utilização da palavra "casta", que começou a ser utilizada por Podemos

24 Sobre esta formulação, ver também: Errejón e Mouffe, 2015. 
no debate político. Para Errejón, o termo "casta" tem se instalado porque explica de forma simples um processo complexo pelo qual as elites políticas e econômicas têm se convertido em um poder único que controla os diferentes mecanismos do Estado, e esse exercício tem garantido o afastamento do controle da sociedade, construindo assim a dicotomia entre casta e sociedade (ERREJÓN, 2014b, p. 35).

Outro fator se relaciona com a crise do regime. Para Iglesias Turrión (2015a), a crise econômica gerou na Espanha, como em outros países europeus, uma crise orgânica que em termos políticos teve como consequência uma crise do regime, isto é - continua Iglesias -, o esgotamento do modelo político e social que foi implementado no processo de transição espanhola, transição entre a ditadura de Franco e a democracia que surge após a morte do ditador em $1975^{25}$. Essa transição se caracterizou pela manutenção do poder dos setores econômicos que se consolidaram durante a ditadura de Franco e pela continuidade das elites políticas que mantiveram posiçóes de poder no Estado no período pós-ditadura. Esse processo se cristalizou na Constituição de 1978 e nos Pactos de Moncloa, que tinham como objetivo construir uma transiçáa pactuada entre as elites políticas do franquismo e as forças da oposição democrática. Uma das consequências desses pactos foi o compromisso de aumentos moderados de salários e o fim do ciclo das lutas operárias do período; a contrapartida seria um conjunto de benefícios sociais e a promessa do desenvolvimento social e econômico que beneficiaria os setores trabalhadores (IGLESIAS TURRIÓN, 2015a, p. 16).

O surgimento do movimento político $15 \mathrm{M}$, ou indignados, foi a maior expressão política e social da crise orgânica e foi consequência da crise do regime político construído durante a transição espanhola. $\mathrm{O}$ fracasso das políticas de austeridade, na avaliação de Iglesias Turrión, tem levado à frustação de expectativas de importantes setores da populaçáo espanhola. Esse elemento foi fundamental para entender as possibilidades políticas que se abriram depois das manifestaçóes de 2011. O movimento do $15 \mathrm{M}$ foi a expressão mais clara do sentimento de frustação, frustação esta que não encontrou expressão no interior da estrutura política do país, revelando a

25 Para outra análise convergente com esta leitura do processo de transição, ver: Monedero, 201 I. 
profunda crise do sistema político espanhol, inclusive da própria esquerda. No entanto essa crise também abriu uma janela de oportunidades para o surgimento de novas ferramentas políticas de transformação (IGLESIAS TURRIÓN, 2015a, p. 17).

Um terceiro fator, segundo Iglesias, fundamental para a definição da hipótese Podemos foi La Tuerka. La Tuerka foi um programa televisivo criado em 2010 por um grupo de professores e alunos vinculados à Faculdade de Ciências Políticas e Sociologia da Universidade Complutense de Madrid, dirigido e apresentado por Pablo Iglesias ${ }^{26}$. Essa experiência de mídia alternativa foi elaborada desde o começo como parte de uma estratégia de construção de uma ferramenta de intervenção política. Para Iglesias, La Tuerka, primeiro, e Fort Apache ${ }^{27}$, depois, foram os partidos políticos a partir dos quais se praticava a luta política no âmbito da comunicação de massas, o terreno fundamental da luta ideológica. Essas experiências se transformaram em espaços fundamentais de formação política, junto com o trabalho de assessoria de comunicação política desenvolvido simultaneamente na Espanha e na América Latina. Essas tentativas de construção de espaços de comunicação alternativos foram um elemento imprescindível da hipótese Podemos: "[...] a possibilidade de liderança de uma figura midiática que desfruta de um altíssimo nível de conhecimento na Espanha” (IGLESIAS TURRIÓN, 2015a, p. 21) 28. A partir de maio de 2013, com a presença constante de Pablo Iglesias na mídia, começou a reflexão sobre a forma de usar esse protagonismo midiático para intervir na cena política espanhola.

$\mathrm{Na}$ análise de Iglesias, não existia possibilidade de construção de uma ferramenta político-eleitoral com possibilidade de vitória se a discussão ficasse delimitada ao terreno simbólico esquerda-direita. Era necessário, portanto, um combate ideológico e o estabelecimento de uma estratégia que identificasse os limites para definir um novo cenário e o discurso

\footnotetext{
26 Ver: http://www.latuerka.net. Para uma análise mais detalhada da experiência, ver: Giménez, 20I4b.

27 Fort Apache, também conduzido por Pablo Iglesias Turrión, tinha como proposta ser um programa de debate político no qual se discutiam temas de atualidade da Espanha e da América Latina. Em seu formato, além do apresentador, havia seis convidados que discutiam diferentes pontos de vista do assunto. Mais informações disponíveis em: http://www.fortapache.es. 
necessário para impor esse novo cenário na esfera da mídia. Para Iglesias Turrión (2015a, p. 21): "Disputar a divisão simbólica de posições com o adversário, disputar os 'termos da conversa', foi nossa tarefa político-discursiva mais importante. Em política, quem decide os termos da disputa decide em grande medida seu resultado”.

Como afirma Kopittke (2018), na hipótese Podemos estão concentrados vários temas importantes que aparecem na literatura sobre o fenômeno populista. Um dos elementos que aparece é a relação entre representante e representado e a figura do líder. A outra questáo que surge é o tema da articulação de demandas como momento do surgimento do sujeito povo (KOPITTKE, 2018). Iremos aprofundar estas questóes a seguir.

\section{0 fenômeno populista}

Antes de retomar a questáo da identidade política desta organização a partir das ideias da hipótese Podemos é necessário recuperar - muito brevemente - alguns elementos da discussão sobre o fenômeno populista. Consideramos que tal análise é fundamental para poder discutir a caracterização de Podemos como um fenômeno populista ou um fenômeno com outras influências políticas e teóricas.

Uma das definiçóes mais difundidas do fenômeno populista é aquela elaborada por Cas Mudde (2004, p. 543), o autor que explica o populismo como uma ideologia que considera a sociedade, em última instância, separada em dois grupos homogêneos e antagônicos, de um lado o povo e de outro as elites corruptas, e que a política deve ser expressão da vontade geral do povo.

Para Mudde o fenômeno populista tem um componente moral fundamental, mais que programático. $\mathrm{O}$ essencial da ideologia populista, afirma o autor, não é a diferença entre valores ou posiçôes políticas diversas, e sim a distinçáo normativa entre o puro - o povo - e o corrompido - as elites. E, como consequência dessa distinção insuperável, o acordo político é impossível de ser alcançado (MUDDE, 2004, p. 544).

Para Mudde o populismo deve ser considerado uma ideologia "delgada" ("thin-centered ideology"), limitada do ponto de vista da sua complexidade 
e do seu repertório de conceitos analíticos. O conceito político central é, claro, o povo, e o conceito de elite se constrói por oposição ao primeiro. Como uma ideologia delgada, prossegue o autor, o populismo pode se combinar com outras ideologias, como nacionalismo, socialismo ou liberalismo (MUDDE, 2004, p. 544).

A conceitualização do populismo como uma ideologia ou como uma ideologia levemente centrada, ou incompleta, e que pode ser complementada com outras ideologias tem consequências teóricas importantes.

Como afirma Aslanidis (2015), caracterizar o populismo como uma ideologia delgada implica reconhecer a ausência de um dos elementos fundamentais na definição de ideologia, o elemento de coerência. Os autores que trabalham com essa definição sustentam que o poder e a relevância do populismo se baseiam na sua natureza camaleônica e na sua habilidade para se combinar com outras ideologias dependendo do contexto ${ }^{29}$. Essa é a razão pela qual, como afirma o autor, comumente se identificam como populistas diversos fenômenos, com perspectivas políticas bem diferentes, e até mesmo contrárias (ASLANIDIS, 2015, p. 2).

Para Aslanidis (2015), os casos apresentados pela literatura como exemplos de fenômenos populistas mostram que não existe nenhuma coerência política entre eles. Também do ponto de vista de propostas específicas, dificilmente é possível encontrar similitudes entre os exemplos citados. Para o autor, analisar o populismo como uma ideologia delgada apresenta problemas teóricos e metodológicos fundamentais que devem ser discutidos (ASLANIDIS, 2015, p. 2).

A interpretação do populismo como uma ideologia delgada, sustenta Aslanidis (2015), enfrenta problemas: a noção de "delgada" é muito questionável do ponto de vista conceitual; também existem inconsistências metodológicas importantes no arcabouço conceitual dos autores que propóem essa perspectiva; por fim, existem conotaçóes essencialistas que colocam obstáculos para sua operacionalização (ASLANIDIS, 2015, p. 2).

Dessa forma, Aslanidis propóe que o populismo deve ser considerado um discurso ou uma prática discursiva. Se for afastado o elemento de

29 Este argumento aparece, por exemplo, em: Mudde e Rovira Kaltwasser, 2013. 
caráter ideológico que aparece na formulação de Mudde, continua o autor, chegamos a uma definição puramente discursiva: o populismo se transforma em um discurso, que invoca o povo contra as elites afirmando que a soberania política reside no primeiro. Para o autor, essa é a forma como o conceito tem sido operacionalizado pela literatura recente que discute o fenômeno populista (ASLANIDIS, 2015, p. 9). Essa vertente discursiva da literatura sobre o populismo tem como uma de suas principais referências as obras de Ernesto Laclau e de Chantal Mouffe ${ }^{30}$. Os autores têm recusado definir o populismo a partir de dimensóes sociais ou econômicas, e focam sua análise na construção discursiva do apelo populista (ASLANIDIS, 2015, p. 10).

A perspectiva analítica do populismo a partir da vertente discursiva contribuiu, como afirmam Stavrakakis e Katsambekis (2014), com dois elementos importantes para superar vários problemas conceituais. Esses elementos permitem analisar uma prática discursiva. $\mathrm{O}$ primeiro elemento questiona se a prática discursiva articula-se em torno de um ponto nodal, por exemplo "o povo", ou em torno de vários, como classe, liberdade, naçáo etc. O segundo elemento verifica se a representação oferecida por essa prática constitui uma representação da sociedade basicamente antagônica, dividida entre o povo e as elites. Esses dois elementos devem estar presentes para que um discurso ou movimento seja classificado como populista. O processo de construção do discurso populista, afirmam os autores, se estabelece a partir de um conjunto de demandas insatisfeitas que entram em relaçóes de equivalências e, dessa forma, constroem uma identidade coletiva chamada povo; essa identidade coletiva, por sua vez, será representada pelo líder. Outro fator importante levantado pelos autores é que a cadeia de equivalências, que elimina a heterogeneidade das demandas, é construída mediante uma lógica antagônica, impugnando um inimigo comum: as elites, responsáveis por frustrar as demandas populares (STAVRAKAKIS; KATSAMBEKIS, 2014, p. 123).

A discussão sobre o populismo também tem sido central para analisar a nova configuração política recente na Europa e também a situação

30 Ver, entre outros: Laclau e Mouffe, 1987; Laclau, 2005, 2007; Mouffe, 1993, 1995. 
política na Espanha a partir do surgimento da organização política Podemos. Como afirma Franzé (2017, p. 220), na literatura que discute a identidade política de Podemos, a principal pergunta gira em torno do caráter populista da organização.

Alguns autores, como José Luis Villacañas, discutem as condições de emergência do populismo na Espanha vinculadas à crise econômica, social e de representação política. Para Villacañas, tempos de extrema complexidade, como os que viveu o país, sáo momentos propicios para o surgimento de fenômenos como o populismo. O 15M, prossegue o autor, e a crise do sistema político abriram as portas para uma politica populista na Espanha. Nessa situação de crise, a dicotomia amigo/inimigo do povo própria da lógica populista foi facilmente instalada no espaço público (VILLACAÑAS, 2015).

Franzé analisa a trajetória do discurso de Podemos com base nos conceitos de antagonismo, de Laclau, e de agonismo, de Mouffe. Para o autor, o discurso de Podemos se transformou, ao longo do tempo, de um discurso com base no antagonismo, entendido como relaçáo de inimizade com a ordem política, em um discurso que enfatizava o elemento agonista, que representa uma relação de adversário e não de inimigo. Essa adaptação do discurso, afirma o autor, não implicaria uma moderação da formação política, e sim uma mudança de estratégia para a construção de uma nova hegemonia política (FRANZÉ, 2017, p. 220).

Valdivielso (2017) também discute o fenômeno Podemos a partir da teoria elaborada por Laclau e Mouffe, particularmente com base nos conceitos propostos no livro $A$ razáo populista. Para o autor, Podemos utiliza a noção de populismo de forma seletiva, e os dirigentes da organização têm ideias diferentes de como construir democraticamente o povo. Seu artigo analisa as tensóes da hipótese populista de Podemos e discute um possível distanciamento da estratégia de construção da hegemonia política com relação às propostas colocadas por Laclau na construção do sujeito político povo (VALDIVIELSO, 2017, p. 1-2).

Apesar das diferenças nas perspectivas colocadas por esses autores, existe um ponto em comum nas análises, o pressuposto da identidade populista de Podemos. Na próxima seção, tentaremos fazer uma análise crítica sobre a identidade dessa formação política recuperando algumas das teses da teorização de Laclau. 


\section{Populismo de esquerda ou alternativa política de esquerda}

O texto de Ernesto Laclau, A razáo populista, tem sido uma das principais referências teóricas na discussão sobre o populismo, e é particularmente importante na interpretação do populismo de Podemos. Como colocávamos anteriormente, na elaboração da hipótese Podemos existem elementos que remetem às formulaçóes desenvolvidas pelo autor argentino na obra citada e que gostaríamos de problematizar neste ponto do artigo.

Laclau (2005, p. 9) começa $A$ razão populista afirmando que o "livro se interroga centralmente sobre a lógica de formação das identidades coletivas". O enfoque, na proposta do autor, buscava superar uma insatisfação com certas perspectivas funcionalistas ou estruturalistas que examinavam as identidades coletivas considerando o grupo como a unidade básica de análise.

Laclau, nesse sentido, critica a leitura dominante que associava o populismo com um fenômeno perigoso que questionaria a legitimidade de uma ordem política racional. Segundo a interpretação de Laclau (2010, p. 10), o populismo teria uma lógica específica, que não seria marginal, e que responderia ao funcionamento de qualquer espaço comunitário.

Como afirma o autor:

Nosso intento não tem sido encontrar o verdadeiro referente do populismo, mas fazer o contrário: mostrar que o populismo não tem nenhuma unidade referencial porque não é atribuível a um fenômeno delimitável, mas a uma lógica social cujos efeitos atravessam uma variedade de fenômenos. O populismo é, simplesmente, um modo de construir o político. (LACLAU, 2005, p. II, ênfase nossa).

A partir desta perspectiva, Laclau vai argumentar que o sujeito central, na lógica populista, vai ser o povo. O povo como sujeito político se constituiria a partir de uma pluralidade de demandas sociais, muitas delas diversas e contraditórias. No entanto, Laclau vai diferenciar entre "demandas democráticas" e "demandas populares"; só a partir dessas últimas é possível a construção do povo como ator histórico. As demandas democráticas são, para o autor, aquelas que permanecem isoladas, tanto se são satisfeitas quanto se permanecem insatisfeitas; já as demandas populares são aquelas 
que, por sua articulação, podem constituir uma subjetividade mais ampla capaz de se transformar em um ator histórico (LACLAU, 2005, p. 99).

Como afirma Laclau (2005, p. 142):

( I ) o surgimento do povo requer a passagem - via equivalencial - de demandas isoladas, heterogêneas, a uma demanda "global" que implica a formação de fronteiras políticas e a construção discursiva do poder como força antagônica; (2) no entanto, como essa passagem não é resultado de uma mera análise de demandas heterogêneas como tais - não é uma transição lógica, dialética ou semiótica de um nível a outro -, deve intervir algo qualitativamente novo.

Esse algo qualitativamente novo, que o autor chama de "investidura radical”, pertence à ordem do afeto (LACLAU, 2005, p. 142).

Chantal Mouffe (2018), na sua obra mais recente For a Left Populism, também enfatiza este registro afetivo como um elemento fundamental na construção de demandas democráticas que caracterizariam o "momento populista”. Este elemento afetivo seria central para a construção de práticas contra-hegemônicas e consensos post-políticos que passam pela construção de fronteiras políticas. Dessa forma, a estratégia de um "populismo de esquerda" implicaria a construção em uma lógica populista, de uma oposição entre o "povo" e a "oligarquia", nesta confrontação de espaços, o "povo" se constituiria mediante a "articulação de uma variedade de demandas democráticas” (MOUFEE, 2018, p. 41).

Uma crítica que tem se dirigido contra esta formulação do fenômeno populista, particularmente importante para a discussão sobre Podemos, é que essa pluralidade de demandas - retomando os argumentos colocados por Álvarez Yágues - não desaparecia somente como resultado do estabelecimento de uma cadeia de equivalências entre as distintas demandas populares, construído com base na instituição de uma dicotomia política radical, mas por causa do sentimento de pertencimento comum ao que seria um conjunto étnico ou uma nação. As diferenças entre as demandas sociais, prossegue o autor, não desapareceriam como resultado de um articulação superadora, mas como resultado de uma "dissolução imaginária" (ÁLVAREZ YÁGUES, 2018, p. 208).

Como afirma Álvarez Yágues (2018), no interior da lógica populista o povo se constitui como um corpo político no qual se articulam demandas de diferentes grupos sociais, mas como um todo que constitui a sua 
unidade a partir da construção da identidade com o líder. As diferenças de interesses e conflitos são suprimidas ou ocultadas - continua o autor - em uma operação retórica na qual o elemento afetivo substitui o intelectual no processo de identificação. Ainda que Laclau afirme que o sujeito se constrói politicamente, assistimos - como sustenta Álvarez Yágues - a um processo de naturalização no qual o sujeito não se autopercebe, mas aparece como um fenômeno já existente e não construído pela lógica politica (ÁLVAREZ YÁGUES, 2018, p. 208).

Dessa forma, afirma Álvarez, não temos aqui a articulação de diversos interesses sob a hegemonia de determinada classe ou grupo social, mas o povo como uma massa indiferenciada que só sai dessa condição na corporeidade dada pelo líder. Assim, prossegue o autor, chegamos à questão de deixar de lado a dicotomia entre esquerda e direita, que seria uma possível divisão de caráter político, quando na realidade a constituição do sujeito povo permitiria superar essa divisão. Mais importante é a dicotomia acima/abaixo, uma dicotomia que permite separar o povo daqueles que não são parte dele, uma divisão - como alega Álvarez Yágues - que parece natural e não resultado de uma decisão ou estratégia política. Logo, a operação de construção do povo não aparecia como um processo artificial, mas sim como a retirada dos obstáculos que impediriam que o verdadeiro sujeito político, o povo, se manifestasse (ÁLVAREZ YÁGUES, 2018, p. 209).

No caso de Podemos, acreditamos que não estamos ante essa ideia do povo, entendido nos termos colocados por Laclau, como sujeito político do processo de transformação, e sim diante da tentativa de articulaçáo de um conjunto de demandas democráticas ${ }^{31}$ que não contam com expressão política ${ }^{32}$.

Algumas definições fundamentais sobre Podemos podem ser encontradas nos documentos aprovados no Congresso de Vistalegre $\mathrm{II}^{33}$, realizado em fevereiro de 2017, e que ajudam a entender melhor a identidade

31 Sobre as demandas democráticas defendidas por Podemos, ver: https://podemos.info/las20depodemos/.

32 Villacañas também defende a ideia de que as demandas das Mareas sociais, que serão retomadas por Podemos, são demandas setoriais e democráticas, por exemplo, a defesa da educação e da saúde pública, a luta contra os despejos e a luta dos afetados pela hepatite. Eram defendidas, afirma o autor, por "coletivos de profissionais, [tinham] interesses parciais, não reclamos populistas" (VILLACAÑAS, 2015, p. 124). 
política dessa organização. O documento político parte de uma análise do esgotamento da forma clássica de partido e da busca por criar outras formas de organização mais de acordo com as necessidades da cidadania, mas não há nessa análise um apelo à criação do sujeito povo por meio da articulação de demandas populares ${ }^{34}$. Por outro lado, parece bastante claro que as identidades já existem no campo do social, no entanto os partidos majoritários teriam deixado de representar seus interesses para representar exclusivamente seus interesses próprios ${ }^{35}$.

Como afirma o documento:

Podemos, que nasce do esgotamento do bipartidarismo e de seus apoios, tem de seguir construindo com outros atores o espaço político da mudança em um país, ademais, especialmente complexo por sua construção histórica de nosso Estado e nosso caráter plurinacional. A lógica deve ser, portanto, a da unidade na diversidade: um projeto compartilhado por identidades políticas, sociais e territoriais diversas, em que o que é uma cotidianidade se articule no âmbito do político. (PODEMOS PARA TODOS, 2017a, p. 30, grifos nossos).

Uma ideia similar aparece na análise de Iglesias Turrión, para quem Podemos é a força política de referência das classes populares. Aqui as classes populares são entendidas como um conjunto de setores afetados pela crise econômica, trabalhadores públicos, autônomos, pequenos empresários, jovens desempregados e a classe operária. Iglesias Turrión sustenta que existe uma dicotomia entre "a política de compromisso com as elites e a que defende os setores populares”. Ainda que aqui apareça o recurso retórico que separa a sociedade em dois campos políticos, na nossa interpretação isso é bastante diferente da lógica discursiva populista proposta por Laclau (IGLESIAS TURRIÓN, 2015b, p. 69-70).

O documento político anteriormente mencionado também coloca a necessidade de um esforço militante nos diferentes níveis, tanto nas instituiçóes quanto nos bairros e povoados, para poder construir um novo bloco social e popular. Dois elementos importantes aparecem nessa parte do documento: quanto à questão das alianças sociais, aparece a ideia de uma

\footnotetext{
34 Ver também: Iglesias Turrión, (2015a, p. 93) sobre como o 15M colocou em crise as formas de organização política existentes, inclusive da esquerda.

35 Ver também: Monedero, 2016.
} 
articulação política entre os movimentos sociais e Podemos como forma de potencializar o trabalho político, mas também de reforçar as reivindicações apresentadas pelos movimentos; quanto às demandas sociais, preconiza-se que devem ser colocadas no centro da agenda política da organização (PODEMOS PARA TODOS, 2017a, p. 26-27).

Como afirma o documento, a proposta não se restringe à construção de uma organização política, ela vai além e busca construir, em uma linguagem claramente gramsciana, um novo bloco social que permita uma transformação da sociedade espanhola:

Precisamos desenvolver uma pedagogia da práxis que mostre que em situações concretas as pessoas podem vencer as elites e seus representantes. Deter um despejo é uma vitória popular, estar a serviço dos setores que defendem seus direitos deve favorecer mais vitórias populares que consolidem o bloco de mudanças. Ganharemos se essas vitórias não forem de Podemos, mas do bloco social e popular. (PODEMOS PARA TODOS, 2017a, p. 27, grifo nosso).

O objetivo político que aparece no texto é criar uma rede de contrapoder que permita articular as diversas redes sociais para construir um "novo sentido comum majoritário como condiçáo de possibilidade para um impulso constituinte” (PODEMOS PARA TODOS, 2017a, p. 29). A ideia de um novo sentido comum tem também uma conotação claramente gramsciana ${ }^{36}$.

Outro tópico importante na debate do populismo como lógica discursiva é a questão da relação entre sujeito político, representaçáo e democracia. Nesse ponto, o discurso e as práticas políticas de Podemos parecem se afastar bastante das premissas colocadas pela razão populista.

Para Laclau (2005), a função do representante não seria simplesmente transmitir a vontade de aqueles que representa, mas agregar um elemento de credibilidade diferente daquele em que foi constituído. Nesse sentido, Laclau critica as teorias clássicas da representação, como o modelo agregativo

36 As referências ao pensamento de Gramsci também são bastante habituais nos textos de Pablo Iglesias; ver, por exemplo, Iglesias Turrión, 2015, capítulos: "Grecia: la democracia frente al miedo", "Guerra de trincheras y estrategias electoral" e "Manolo: vaya pedazo de cabrón". Outro autor que também exerce influência no pensamento da direção de Podemos é Boaventura de Sousa Santos. Ver: Monedero, 2016. 
de interesses ou o modelo deliberativo, nas quais a vontade popular estaria constituída "antes da representação". Na leitura de Laclau, a representação é o que constitui a própria identidade do sujeito povo. Nesse ponto, o autor retoma os argumentos apresentados por Hanna Fenichel Pitkin no seu clássico livro The Concept of Representation e discute, especificamente, a questão da "representação simbólica" (LACLAU, 2005, p. 201-206).

Laclau (2005), por sua parte, recupera a ideia de representação simbólica como um tipo de representação característica da lógica populista que permitiria homogeneizar uma massa social heterogênea ${ }^{37}$. Retomando a análise de Pitkin sobre a representação simbólica, Laclau resgata que esse tipo de representação permitiria a união da nação em um todo unificado - um símbolo espetacular teria mais eficácia no processo de criação de uma nação que toda uma legislatura de representantes. A verdadeira representação seria o carisma; afirma Laclau (2005, p. 202): "O líder se converte assim em um produtor de símbolos, e sua atividade, já não concebida como 'atuar para' seus eleitores, começa a se identificar com uma liderança efetiva" ${ }^{38}$

Para Álvarez Yágues (2018, p. 214), por sua vez, uma concepção da constituição do sujeito político que implique uma concepçáo unitária do sujeito povo como da sua representação simbólica, como a proposta por Laclau, tem claras consequências antidemocráticas. Em primeiro lugar, continua o autor, estabelece-se um tipo de relação entre líder e povo de caráter direto e sem nenhuma mediaçáo. Em segundo, esse tipo de relaçáo entre líder e povo colocada pela lógica do populismo implica eliminar o papel das organizaçóes políticas no processo deliberativo que pudesse estruturar as demandas sociais. Um terceiro elemento é o profundo anti-institucionalismo da lógica populista, como consequência dessa relação entre sujeito político e representaçáo: o apelo à cidadania aparece não em chave participativa ou deliberativa, mas de forma instrumental, o que tem claras consequências cesaristas e autoritárias. Se existe um elemento positivo nesse apelo do populismo à participação no espaço público e à ação

37 Sobre a questão da heterogeneidade social, ver: Laclau, 2005, Capítulo 5.

38 Em outra parte do texto, Laclau (2005, p. 203) afirma: "o ponto de partida de uma identidade que não precede, mas que é resultado do processo de representação". 
política dos grupos sociais, o elemento instrumental acaba por neutralizar o potencial democrático (ÁLVAREZ YÁGUES, 2018, p. 214).

A questão da representação política apareceu desde o começo como um dos elementos centrais da estratégia política de Podemos cujo ponto de partida era uma crítica ao sistema político espanhol e a crise de representação dos partidos políticos surgidos na transição democrática. No documento inicial do movimento, essa questáo aparece de forma clara: era necessária uma candidatura que representasse a indignação popular e exigisse uma melhor representação, uma maior horizontalidade, mais transparência e justiça social (MONEDERO et al., 2014, p. 2).

O espaço político que estava surgindo requeria que a escolha de representantes fosse resultado de um processo participativo aberto à cidadania, na elaboração de seu programa e na composição das listas com a presença de ativistas sociais, políticos e culturais, e a rotatividades nos cargos (MONEDERO et al., 2014, p. 4). Aqui a representação não é entendida no sentido de representação simbólica de Laclau nem do líder como elemento central de criação do sujeito político.

A estrutura organizativa e a lógica política da organização Podemos também parecem estar bastante afastados do tipo de relaçáo entre líder e povo construída na lógica do populismo, ainda que existam críticas a um excesso de centralismo na figura de Pablo Iglesias. Independentemente dessas críticas, existe uma organização política democrática, com diversos órgãos colegiados e milhares de organizaçóes de base chamadas de círcu$\operatorname{los}^{39}$. A organização e a consulta às bases em um tipo de democracia direta on-line também têm papel fundamental no processo deliberativo para a elaboração das propostas políticas e dos programas eleitorais.

No documento organizativo aprovado também no Congresso de Vistalegre $\mathrm{II}^{40}$, com o título de clara referência zapatista "Mandar obedecendo", define-se Podemos como "[...] expressáo política de um processo

39 Sobre esta estrutura organizativa interna, ver: Podemos para todos, 20I7b.

40 Cabe destacar que os documentos aprovados no Congresso de Vistalegre II são os documentos oficiais de Podemos e que regem a vida partidária, a estrutura organizativa interna e a estratégia política e eleitoral da organização. 
maciço de fortalecimento popular" e "expressão política de uma vontade democrática” (PODEMOS PARA TODOS, 2017b, p. 5). No documento, afirma-se que Podemos deve ser uma ferramenta de transformação política em consonância com o processo de mobilização que emergiu com o $15 \mathrm{M}$ e os movimentos sociais articulados posteriormente em defesa dos direitos sociais da população (PODEMOS PARA TODOS, 2017b).

O documento também afirma a necessidade de recuperação do controle democrático das instituições e democratização real da participação política. Para isso,

[...] tem sido necessário imaginar um projeto político de novo tipo, enraizado na realidade popular, sustentado e articulado na ação social efetiva, comprometido com a participação, o debate público, a transparência e a prestação de contas como eixos dos processos políticos democráticos. (PODEMOS PARA TODOS, 2017b, p. 5).

Outro elemento importante apresentado no documento se refere ao trabalho nas instituiçóes, e que parece bem distante do anti-institucionalismo presente na discussão sobre a questão da representação, analisada anteriormente. No documento, afirma-se a necessidade de recuperar as instituiçôes democráticas e redefinir as políticas públicas com base nas necessidades da cidadania, de forma que os "problemas individuais se transformem em obrigações institucionais” (PODEMOS PARA TODOS, 2017a, p. 27). As açôes institucionais, portanto, são prioritárias do ponto de vista da construção de uma estratégia política de transformação, e são enfatizadas as diversas estratégias de trabalho institucional para as Prefeituras das mudanças, os Parlamentos Autônomos e o Congresso (PODEMOS PARA TODOS, 2017a).

$\mathrm{O}$ documento refere-se, ainda, à relação entre o espaço institucional e o espaço político fora das instituiçóes. Para os autores do documento, não existe uma contradição entre o trabalho institucional e o trabalho dos movimentos sociais fora das instituiçôes, o que existe é uma tensão que se modifica dependendo da conjuntura política. Como parte dessa leitura, o documento apresenta uma análise e uma estratégia sobre a luta institucional:

Se nos subordinamos à lógica institucional, dissolvemo-nos, e se, pelo contrário, nos limitamos ao conhecido e já transitado, nós nos autoexcluímos. A dialética movimento-instituição 
(um equilibrio instável permanente) não termina nunca, no entanto deve servir para avançar na transformação e superação da ordem institucional atual. Por isso devemos seguir construindo o bloco histórico, social e popular - essa união de setores que se encontram porque coincidem em seus diagnósticos, seus interesses e seus objetivos - que faz política ao mesmo tempo nas instituições e nos espaços públicos não institucionais. (PODEMOS PARA TODOS, 2017a, p. 28, grifos do original).

Do ponto de vista da estratégia para as eleiçóes gerais de 2020, o documento destaca a articulação entre instituiçôes e movimentos sociais e afirma a necessidade de "[...] transladar às instituiçôes as iniciativas dos movimentos sociais e, [...] respeitando a independência das organizaçóes da sociedade civil, colaborar com seu crescimento e fortalecimento social" (PODEMOS PARA TODOS, 2017a, p. 29).

\section{Considerações finais}

O surgimento de Podemos teve consequências positivas para a política e para a democracia espanhola, trazendo novas demandas, colocando em crise um bipartidarismo esgotado, que se consolidou durante a transição democrática, e permitindo uma ampliação da participação da cidadania nos assuntos públicos.

Outro elemento importante, como afirmam Sola e Rendueles (2017), foi a reconfiguração do debate político, introduzindo novos temas e novas formas de expressáo e diálogos com a cidadania. Para os autores, Podemos conseguiu inserir no debate público ideias, demandas e símbolos que surgiram nas praças espanholas durante o $15 \mathrm{M}$, o que implicou um revigoramento importante da vida democrática do país (SOLA; RENDUELES, 2017, p. 12-13).

Do ponto de vista da agenda política, com a emergência de Podemos declaram Sola e Rendueles - houve uma ampliação dos temas e problemas colocados em debate. Problemas fundamentais da cidadania foram colocados no centro da discussão pública, por exemplo, a denúncia da conivência entre partidos políticos e setores empresariais (tanto os conflitos de interesses quanto os financiamentos ilegais dos partidos), um conjunto de direitos sociais negados a setores importantes da população (direito a moradia, emprego, renda mínima, e saúde e educação públicas de qualidade) 
e a crítica às políticas de austeridade fiscal impostas pela Troika com suas graves consequências sociais (SOLA; RENDUELES, 2017, p. 13).

No entanto, e apesar dos elementos positivos da emergência de Podemos como nova força no cenário político espanhol, permanece a questão da hipótese Podemos ou a indagação referente à possibilidade de caracterizar Podemos como um populismo de esquerda. Dessa forma, analisaremos as caracterizaçôes de alguns trabalhos sobre o tema para chegar a nossas próprias conclusões.

Para Kopittke (2018), Podemos poderia ser caracterizado como um fenômeno populista considerando que tinha com conjunto de demandas potencialmente articuláveis e um líder carismático. No entanto, a fraqueza dos pontos nodais talvez exigira um antagonismo mais intenso ou mais vazio do que apresentou. Continua o autor: "O populismo deliberado sempre terá algo de estranho, o populismo teorizado e praticado, sempre terá algo de impróprio, e nos parece, não favorece nem carisma, nem antagonismo" (KOPITTKE, 2018, p. 180).

Sola e Rendueles (2017, p. 15) afirmam que: "Podemos é um caso de 'populismo de esquerda', isto é, uma lógica discursiva populista construída com princípios, fins e politicas de esquerda" ${ }^{4}$. No entanto, tal conclusão não parece ser consequência necessária da análise desenvolvida ao longo do artigo, e sim um pressuposto colocado pelos autores. Em outra parte do texto aparece uma ideia diferente, a de que Podemos emerge denunciando a crise na democracia espanhola, e [de que] o populismo da organização "[...] tem sido a mais frequente acusação levantada contra ele - no entanto [...], o partido tem contribuído para a repolitização do debate público" (SOLA; RENDUELES, 2017, p. 14) . $^{42}$

Assim, parece haver certa ambiguidade na caracterização de Podemos como um fenômeno populista. Para os autores, o fenômeno de

41 Contudo, em outra parte do texto aparece a afirmação do populismo não como lógica discursiva, mas sim como ideologia, o que, como vimos, apresentaria um conjunto importante de problemas teóricos. Afirmam os autores: "Em nível ideológico, o populismo de Podemos é, sem dúvida nenhuma, uma versão europeia de populismo de esquerda” (SOLA; RENDUELES, 2017, p. 6).

42 Em outra parte do texto aparece ideia similar: "[...] a crítica mais recorrente que Podemos tem recebido de parte de seus oponentes políticos e da maioria da imprensa tem sido, sem dúvida, que é uma força populista" (SOLA; RENDUELES, 2017, p. 13). 
Podemos "desmente as previsões" mais sombrias sobre o populismo; não é possível encontrar traços de xenofobia ou de chauvinismo no seu discurso, tampouco aparece nas linhas políticas da organização uma visão antiliberal da política que recuse os princípios constitucionais de divisão de poderes, que negue a representaçáo como um elemento importante nos regimes democráticos ou que denuncie o "pluralismo em favor de um povo homogêneo" (SOLA; RENDUELES, 2017, p. 14). Segundo os autores, Podemos náo aparece como uma ameaça para a democracia, e sim como um elemento de aprimoramento. Podemos tem trazido e politizado temas que pareciam fora do espaço público, como a intervenção do Estado na economia, a reforma tributária ou medidas contra o ajuste econômico; Sola e Rendueles (2017, p. 14) completam, afirmando: "Ironicamente, essa repolitização tem trazido de volta os eixos esquerda-direita em termos substantivos, sobre questôes distributivas, apesar de um dos carros-chefes de Podemos ter sido abolir esses rótulos".

A pergunta que permanece depois desta análise é: por que caracterizar Podemos como um fenômeno populista?

Em um artigo publicado em setembro de 2016, Jan-Werner Müller, um especialista no tema, questiona a caracterização muito pouco precisa de diversos fenômenos políticos como sendo populista. Analisando os atrativos do populismo para alguns dos principais líderes políticos e seus políticos para a democracia, o autor afirma que não existira razão para caracterizar a Syriza e a Podemos como fenômenos populistas, estas organizaçóes seriam mais tentativas de reinventar partidos de orientação socialdemocrata (MÜLLER, 2016).

Outro autor que considera o mesmo sentido de crítica da generalização da utilização da definição de populismo para qualquer fenômeno político é Álvarez Yágues (2018, p. 220), que afirma:

A caracterização do populismo que fazem cientistas políticos ou sociólogos [...] funciona muito mal no intento de aplicar a partidos como Syriza na Grécia e Podemos na Espanha. Sua mesma procedência, fundamentalmente de organizações que têm o marxismo como sua principal fonte teórica, sua composição intelectual, suas lideranças, os debates internos, sua posição de respeito ao institucional ou ao espaço de representação, ainda que com dúvidas e confusão que não poucas vezes têm sido empregadas, não se encaixam nos pressupostos que definem o populismo. 
Existe, como analisamos anteriormente, uma corrente interna que afirma Podemos como uma organização política populista. No entanto, estamos de acordo com a ideia colocada por Álvarez Yágues (2018) de que o apelo ao populismo de Podemos parece ser uma questão mais de tática política, ou conveniência na construção discursiva, que propriamente de identidade política ${ }^{43}$. Para o autor, há uma contradição insuperável entre o fenômeno populista e a tradição de esquerda e não faria sentido falar de um populismo de esquerda, ainda que no caso latino-americano sejam necessárias consideraçóes particulares sobre o caso.

Afirma o autor:

Sim a política [...] é identificável com democracia no seu sentido mais radical, se a esquerda não pode senão, e antes de tudo, se definir pela sua prática, teríamos que o populismo, porque difere essencialmente dessa categoria, não pode ser de esquerda. (ÁLVAREZ YÁGUES, 2018, p. 219).

Concordando com essa ideia colocada por Álvarez Yágues, acreditamos que certo apelo populista presente no discurso de Podemos, particularmente o apelo "a casta vs. a gente" está menos relacionado à tentativa de criar uma força populista do que a uma tática eleitoral para construir uma força política com vocaçáo hegemônica no espaço político da Espanha.

A hipótese Podemos, afirma Iglesias Turrión, partia da ideia da existência de circunstâncias extraordinárias que permitiam estabelecer um discurso crítico às elites econômicas e políticas do país e em defensa da justiça social; no entanto esse discurso não podia funcionar com a identidade política da esquerda tradicional (IGLESIAS TURRIÓN, 2015b, p. 53).

Em um sentido similar se expressa Monedero, com Podemos não se tratava de reinventar a esquerda clássica, mas "[...] uma nova forma política que faz política de outra forma e que vem a ocupar o lugar da

43 Podemos relacionar essa ideia de um uso tático com a forma de se apropriar de algumas ideias de Laclau para defender determinadas posições - por exemplo, a ideia da autonomia do político -, como afirma Iglesias Turrión (2015a, p. 37, grifo nosso): “Em $A$ razão populista o problema encontra solução abandonando de forma clara o marxismo, eludindo, digamos, o problema em sua totalidade. Eu não me identifico teoricamente com isso, mas sim reconheceria que aí Laclau propõe uma ferramenta, ou um mecanismo teórico, muito útil para efetuar uma interpretação prática da autonomia do político". 
antiga esquerda. Porque essa antiga esquerda já não vale" (MONEDERO, 2016, [s. p.]).

A estratégia política de Podemos implicava ocupar o centro da cena política no país; como consequência, era necessário deixar de lado a identidade, o discurso e as problemáticas que a esquerda "tradicional" tinha colocado ao longo do século XX e ressignificar o discurso e as práticas para buscar construir uma nova hegemonia política.

Para Iglesias Turrión (2015b, p. 54):

Ocupar a centralidade no tabuleiro e estabelecer os termos do debate no país com um relato iniludível para o resto dos atores, que se veem obrigados a se posicionar com relação a este, é a aspiração de qualquer opção política que pretenda ganhar as eleições. No entanto, não há razão para essa centralidade coincidir com a que no passado se chamou "centro ideológico" e que só pode ser explicada no contexto em que conservadores e sociais-democratas conseguem diferenciar suas propostas. Hoje, pelo contrário, a centralidade está marcada pelo que assinalava ZP [José Luis Rodríguez Zapatero]: um projeto político redistributivo ante o dogmatismo da austeridade.

$\mathrm{Na}$ avaliação de Iglesias Turrión, os partidos social-democratas da Europa tinham renunciado a ocupar esse espaço político e isso explicaria a emergência de partidos como Syriza na Grécia e de Podemos na Espanha.

Em suma, acreditamos que a caracterização de Podemos como um populismo de esquerda é uma caracterização que não está de acordo com o discurso político da formação, com a tradição de seus principais dirigentes, nem com a própria estrutura organizativa como força política ${ }^{44}$. Parece mais provável que estejamos assistindo à formaçáo de uma nova força política de esquerda radical na Europa, pós-crise econômica, que busca romper com a tradição da esquerda clássica e da social-democracia na Espanha e cuja identidade ainda está em processo de formação.

\section{Referências}

ÁLVAREZ YÁGUES, J. Permanencia en el populismo, sujeto político y cuestiones de tácticas". In: GALINDO, A.; UJALDÓN BENÍTEZ, E. ¿Quién dijo populismo? Madrid: Editorial Biblioteca Nueva, 2018. p. 199-225.

44 Sobre a caracterização de Podemos como uma oposição de esquerda, ver: Watkins, 2016. 
ARATO, A. Political Theology and Populism. Social Research: An International Quarterly, v. 80, n. 1, p. 143-172, 2013.

ASLANIDIS, P. Is Populism an Ideology? A Refutation and a New Perspective. Political Studies, v. 64 , p. $1-17,2015$.

BESCANSA, C. El éxito social de Podemos. Entrevista a Carolina Bescansa. In: DOMÍNGUEZ, A.; GIMÉNEZ, L. Claro que Podemos. De La Tuerka a la esperanza del cambio en España. Barcelona: Libros del Lince., 2014. p. 119-140.

DOMÍNGUEZ, A.; GIMÉNEZ, L. Claro que Podemos. De La Tuerka a la esperanza del cambio en España. Barcelona: Libros del Lince, 2014.

EL PAÍS. Total Espańa. 2015. Disponível em: http://resultados.elpais.com/elecciones/2015/ generales/congreso/. Acesso em: 15 maio 2018.

ERREJÓN, I. La juventud sin futuro y los riesgos de la política hegemónica. Rebelión, 12 abr. 2011. Disponível em: http://www.rebelion.org/noticia.php?id=126259. Acesso em: 8 maio 2017, 2011a.

ERREJÓN, I. La lucha por la hegemonía durante el primer gobierno del MAS en Bolívia (2006-2009): un análisis discursivo. Tese (Ciência Política). Madrid: Universidad Complutense de Madrid, 2011b.

ERREJÓN, I. "PODEMOS como práctica cultural emergente frente al imaginario neoliberal: hegemonía y disidencia”. Conversación con Íñigo Errejón Galván. IC - Revista Científica de Información y Comunicación, n. 11, p. 17-46, 2014 a.

ERREJÓN, I. "Del estilo Tuerka a la campaña de Podemos. Entrevista Iñigo Errejón”. In: DOMÍNGUEZ, A.; GIMÉNEZ, L. Claro que Podemos. De La Tuerka a la esperanza del cambio en España. Barcelona: Libros del Lince., 2014b. p. 85-117.

ERREJÓN, I.; MOUFFE, C. Construir pueblo. Hegemonía y radicalización de la democracia. Madrid: Icaria Editorial, 2015.

FRANZÉ, J. La trayectoria del discurso de Podemos: del antagonismo al agonismo. Revista Espańola de Ciencia Política, n. 44, p. 219-246, 2017.

GÁLVEZ, J. J.; KADNER, M. Podemos se convierte en la sorpresa y logra cinco escaños en Estrasburgo. El País, 25 maio 2015. Disponível em: http://politica.elpais.com/politica/2014/05/25/ actualidad/1401009854_060215.html. Acesso em: 13 out. 2018.

GIMÉNEZ, L. En la Facultad, Radicales y Mayoritarios”. In: DOMÍNGUEZ, A.; GIMÉNEZ, L. Claro que Podemos. De La Tuerka a la esperanza del cambio en España. Barcelona: Libros del Lince., 2014a. p. 19-26.

GIMÉNEZ, L. La experiencia de la Tuerka. In: DOMÍNGUEZ, A.; GIMÉNEZ, L. Claro que Podemos. De La Tuerka a la esperanza del cambio en Espańa. Barcelona: Libros del Lince, 2014b. p. $27-51$. 
IGLESIAS TURRIÓN, P. Multitud y acción colectiva postnacional: un estudio comparado de los desobedientes: de Italia a Madrid (2000-2005). Tese em Ciência Política. Madrid: Universidad Complutense de Madrid, 2008.

IGLESIAS TURRIÓN, P. Disputar la democracia. Política para tempos de crisis. Madrid: Akal, 2014.

IGLESIAS TURRIÓN, P. Entender Podemos. New Left Review (versão em espanhol), n. 93, p. 9-32, jul./ago. 2015a.

IGLESIAS TURRIÓN, P. Una nueva transición. Materiales del año del cambio. Madrid: Akal, 2015 b.

IGLESIAS TURRIÓN, P.; MONEDERO, J. C. ¡Qué no nos representan! El debate sobre el sistema electoral español. Madrid: Editorial Popular, 2011.

JEREZ, A.; MACEIRAS, S. D’A.; MAESTU, E. Esferas públicas, crisis política e internet: el surgimiento electoral de Podemos. História, Ciências Saúde - Manguinhos, Rio de Janeiro, v. 22, p. 1573-1596, dez. 2015.

KOPITTKE, H. P. Podemos e a hipótese populista na Espanha. Orientador: Ary Cesar Minella. 2018. 192 f. Dissertação (Mestrado em Sociologia Política) - Programa de Pós-graduação em Sociologia Política - Universidade Federal de Santa Catarina, Florianópolis, 2018.

KIOUPKIOLIS, A. Podemos: the ambiguous promises of left-wing populism in contemporary Spain. Journal of Political Ideologies, p. 99-120, 7 mar. 2016.

LACLAU, E. La razón populista. Buenos Aires: Fondo de Cultura Económica, 2005.

LACLAU, E. Emancipation(s). London; New York: Verso, 2007.

LACLAU, E.; MOUFFE, C. Hegemonía y estrategia socialista. Hacia una radicalización de la democracia. Madrid: Siglo XXI, 1987.

MARI-KLOSE, P.; MARTÍNEZ PÉREZ, A. Empobrecimiento en tiempos de crisis: vulnerabilidad y (des)protección en un contexto de adversidad. Panorama Social, n. 22, p. 11-26, 2016.

MARZOLF, H.; GANUZA, E. ¿¿Enemigos o colegas? El 15M y la hipóteis Podemos. EMPIRIA. Revista de Metodología de Ciencias Sociales, n. 33, p. 89-110, enero/abr. 2016.

MONEDERO, J. C. La transición contada a nuestros padres: nocturno de la democracia española. Madrid: Catarata, 2011.

MONEDERO, J. C. Dormíamos y despertamos: el 15M y la reinvención de la democracia. Madrid: Nueva Utopia, 2012.

MONEDERO, J. C. Las debilidades de la hipótesis populista y la construcción de un pueblo en marcha. Público, 5 nov. 2016. Disponível em: https://blogs.publico.es/juan-carlosmonedero/2016/05/11/las-debilidades-de-la-hipotesis-populista-y-la-construccion-de-un-puebloen-marcha/. Acesso em: 20 jun. 2018. 
MOUFFE, C. The Return of the Political. London: Verso, 1993.

MOUFFE, C. Dimensions of Radical Democracy. Pluralism, Citizenship, Community. London; New York: Verso, 1995.

MOUFFE, C. For a Left Populism. London; New York: Verso, 2018.

MUDDE, C. The Populist Zeitgeist. Government and Opposition, v. 39, n. 4, p. 542-563, 2004.

MUDDE, C.; ROVIRA KALTWASSER, C. Exclusionary vs. Inclusionary Populism: Comparing Contemporary Europe and Latin America. Government and Opposition, v. 48, n. 2, p. 147-172, 2013.

MÜlLER, J.-W. Trump, Erdoğan, Farage: The Attractions of Populism for Politics, the Dangers for Democracy. The Guardian, 2 sept. 2016. Disponível em: https://www.theguardian.com/ books/2016/sep/02/trump-erdogan-farage-the-attractions-of-populism-for-politicians-thedangers-for-democracy. Acesso em: 20 set. 2018.

ONATE, P. La movilización ciudadana en España en los albores del siglo XXI: una contextualización para el debate. Revista Espańola de Ciencia Política, n. 33, p. 31-55, nov. 2013.

PASTOR, J. O desafio do Podemos. Da recusa da 'casta' à ruptura com o regime do 'austeritarismo'. Contretemps, n. 25, p. 52-63, abr. 2015.

ROMANOS, E. El 15M y la democracia de los movimientos sociales: la vie des idées. 2011. Disponível em: http://www. booksandideas.net/El-15M-y-la-democracia-de- los.html. Acesso em: 9 set. 2014.

SIMÓN, P. The Challenges of the New Spanish Multipartism: Government Formation Failure and the 2016 General Election”. South European Society and Politics, v. 21, n. 4, p. 493-517, 2017.

SOLA, J.; RENDUELES, C. Podemos, the upheaval of Spanish politics and the challenge of populism”. Journal of Contemporary European Studies, v. 26, p. 99-116, 2017.

STAVRAKAKIS, Y.; KATSAMBEKIS, G. Left-wing populism in the European periphery: the case of SYRIZA. Journal of Political Ideologies, v. 19, n. 2, p. 119-142, 2014.

TAIBO, C. et al. La rebelión de los indignados: Movimiento 15M: Democracia Real ¡Ya! Madrid: Editorial Popular, 2011.

TORREBLANCA, J. C. Asaltar los cielos. Podemos o política después de la crisis. Barcelona: Penguin Random House Grupo Editorial, 2015.

VALDIVIELSO, J. The outraged people. Laclau, Mouffe and the Podemos hypothesis. Constellations, p. 1-14, 2017.

VILLACAÑAS, J. C. Populismo. Madrid: La Huerta Grande, 2015.

WATKINS, S. Oppositions. New Left Review, n. 98, p. 5-30, mar./apr. 2016. 
VILLANUEVA, F. D. Açáo de Contrapoder na Universidade Complutense de Madrid. 1 vídeo (8 min 53 seg.). Disponível em: https://www.youtube.com/watch?v=No1XU5a4alQ. Acesso em: 13 out. 2018.

Documentos Podemos

MONEDERO, J. C. et al. Mover la ficha: convertir la indignación en cambio político. [S. l.]: [S. n.], 2014. Disponível em: http://tratarde.org/wp-content/uploads/2014/01/Manifiesto-MoverFicha-enero-de-2014.pdf. Acesso em: 20 jun. 2018.

PODEMOS. Programa para las elecciones europeas. 2014. Disponível em: http://blogs.elpais. com/files/programa-podemos.pdf. Acesso em: 28 jun. 2018.

PODEMOS. El programa del cambio. Elecciones autonómicas del 2015. Disponível em: https:// podemos.info/wp-content/uploads/2015/05/prog_marco_12.pdf. Acesso em: 14 out. 2018.

Documentos Vistalegre I:

\#CLAROQUEPODEMOS. Borrador de princípios políticos. [S. l.]: [S. n.], 2015.

Documentos Vistalegre II:

PODEMOS PARA TODOS. Plan 2020. Ganar al PP. Gobernar España. Construir Derechos. Documento Político. 2017a. Disponível em: https://files.podemos.info/HihzerN5Ev.pdf. Acesso em: 13 out. 2018.

PODEMOS PARA TODOS. Plan 2020. Ganar al PP. Gobernar España. Construir Derechos. Documento Organizativo. 2017b. Disponível em: https://files.podemos.info/9AMl3us6iC.pdf. Acesso em: 14 out. 2018.

PODEMOS PARA TODOS. Plan 2020. Ganar al PP. Gobernar España. Construir Derechos. Documento Ético. 2017c. Disponível em: https://files.podemos.info/BL2bQhSWUv.pdf. Acesso em: 14 out. 2018. 


\section{The Podemos' hypothesis: the emergence of a new political alternative in Spain post crisis}

\section{Abstract}

The emergence of the political organization Podemos has a huge impact on Spain and Europe; in little more than four years of existence Podemos have become one of the main political forces of the country. Along with the discussion on the reasons for this surprising escalation, began a debate to understand the political identity of Podemos. Diverse authors have characterized this organization as a new version of social democracy, as a radical new left or as a version of populism. The purpose of this article is to discuss the issue of Podemos' political identity, recovering this debate and examining the conceptual elements present in its documents and in the analysis of its leaders. As part of this objective we seek to discuss the political identity of Podemos within the framework of the debate about the populist phenomenon.

Keywords: Populism. Podemos. Spain. Democracy. 